\title{
NUTRITION AND METABOLISM
}

137

ZINC ABSORPIION IN AND DUJRING RECOVERY IIROM SI:VI:RI MAINUTRITION IN CHILDHOOD. Barbara F Golden \& Michat HIN Golden (spn. by Prof J (golding) Tropical Metaholism Research Unit, University of the West indies, Kingston, Jamaica. Present address: Depe Child Ilealth, University of Alecrdecen, Kingston,
Alerdecil.

Severely malnourished Jamaican children have evidence of hoth malabsorption and ain (Zn) deficiency, especially when they are oedematous. However, on high encrgy feeds they are able to gain weight at greatly accelerated rates. By lahelling their feeds with (n) difterence

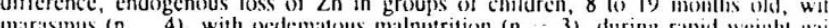

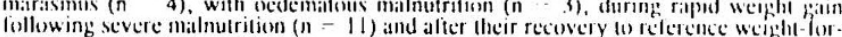
length ('controls', $n=8$ )

length ('controls', $n=8$ ).

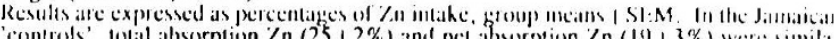

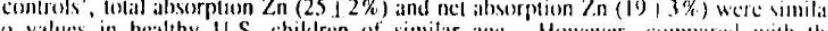
I values in healthy U.S. children of similar age. However, comparced with the

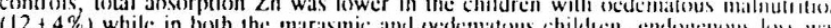
his higher (24,3 vs $9+2 \%$ in the controls): two of the 3 (eedematous children had negative

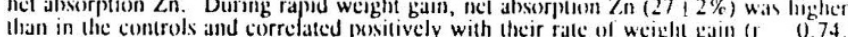
than in the controls and correlated positively with their
$p<0.0 \mid):$ their endogenous loss was low $(5,2 \%)$

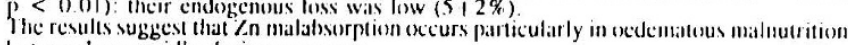
but resolves rapidly during recovery.

140

FIRST TRIMESTER PHENYLKETONURIA (PKU) DIETARY COHTROL AHD NEURODEVELOPMENTAL OUTCOME IN INFAHTS. Ann Lorek, JeHhy Baudan, Jan Townend, Maggie Lilburn, Ann Stewart and David Brenton. Depte of Paediatrics and Medicine, University College London Medical School, Paediatricg

To avold fotal damage in women with pKU, strict preconception and pregnancy control of blood phenylalanine concentrations (PHE) have been recommended (1). To find out if these reconmendations prevented neurological damage we etudied the neurodevelopmental outcome of 24 infants from 23 pregnancies in which strict dietary control was introduced prlor to conception. 18 had reached 1 year. Measures of outcome were related to mean PHE, and to number of daye PHE exceeded $300 \mu \mathrm{mol} / 1$ in the firet trimester. They included head circumference (OFC) and neurological examination at term and 1 year and developmental quotient (Griffithe GQ) at 1 year. The OFC atandard deviation Bcores 496) umol/1 were ignificantiy amaller than those with mean PHE of $<300$ $(139-281) \mu \mathrm{mol} / 1$ (p<0.05). Within the group with mean PHE $<300 \mu \mathrm{mol} / 1$, OFC SDS was lower in those whose PHE exceeded 300 rmol/1 for more than 10 days $(p<0,05)$. 17 of the 24 inf ant 8 examined at term, and 13 of the 18 at 1 (paar, had abnormal neurological 18 at loar, had abnormal neurological aigni. The mean GQ of the 18 infants was $109+13$ and did not differ according to PHE. We conclude that a) waan pHE or $<300 \mu$ mol/1 in the llret trime日ter Lmproves head growth especially when control is atrict b) atrict control at thi 1. MRC Working Party on PKU. Arch Dis Child 2993;68:426-427.

\section{8}

EVALUATION OF THE BODY COMPOSITION AND THE BONE MINERAL CONTENT BY DUAL $X$ RAY ABSORPTIONETRY. A. LAPILLONNE•, B.L.SALLE*, P.BRAILLONS, M.CIIAMBON*. Deparment of Neonatology* and Rhumatology§ 110 pital Edouarú illerriot, LYON, FRANCE

An IIologic QDR $1000 \mathrm{~W}$ system equiped with a special pediatric scanning program was used to evaluate total bone mineral content (BMCt), lean body mass and fat content. 65 infants were studied, gestational age ranged from 36 to 40 wecks : 28 were appropriate for gestational age (AGA), 24 were sniall for gestational age ( $\mathrm{SGA}$ ) and 13 were infants of diabetic mothers (IDM). Mean birth weight (BW) \pm SD was $3116 \pm$ $557,2015 \pm 184$ and $3601 \pm 535$ grams; mean length \pm SD was $49.2 \pm 2.5,4.4 .8 \pm$ 1.9 and $49.8 \pm 2.9 \mathrm{~cm}$ respectively. The scan was performed during the first day of life. BMCl (grams of hydroxyapatite), lean body mass (grams), fat content (grams), \% $B M C t, \%$ fat and \% lean mass were (results were expressed as mean \pm SD)

\begin{tabular}{|c|c|c|c|}
\hline & $\operatorname{AGA}(n=28)$ & $\operatorname{SGA}(n=24)$ & IDN $(n=13)$ \\
\hline BMCl, (grams) & $45.9 \pm 18.1$ & $24.9 \pm 9 \cdots$ & $68.3 \pm 21.70$ \\
\hline (grams) & $457 \pm 148$ & $281 \pm 47 \cdots$ & $804 \pm 24.4 \cdots$ \\
\hline Lean, (grams) & $2481 \pm 401$ & $1658 \pm 170 \cdots$ & $2545 \pm 444$ \\
\hline$\% \mathrm{BMCl}$ & $1.5 \pm 0.4$ & \pm 0.5 . & $1.9 \pm 0.6 \cdots$ \\
\hline$\% \mathrm{Fal}$ & $15.0 \pm 2.7$ & $14.3 \pm 2.1$ & $22.7 \pm 4.9 \cdots$ \\
\hline \% Lean & $83.4 \pm 2.8$ & $80.8 \pm 17.6$ & $73.1 \pm 0 \cdots$ \\
\hline
\end{tabular}

In this gestational age range (36.40 weeks), 1) $B M C t$ in $A G A$ group ditfered from both SGA and IDM caltegories: BMCt wats beller correlated with birthweight than with gestational age. 2) Body composition in \% of BW did not differ significamtly betwee SGA and AGA infants. 3) In IDM infants, fat content increased and thus explained the heavy birthweight.

139

THE SERUM TRANSFERRIN RECEPTOR AS INDICATOR OF IRON DEFICIENCY IN INFANTS

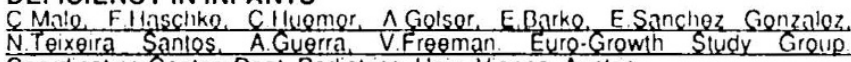
Coordinating Center: Dept. Pediatrics, Univ. Vienna, Austria

政 of iron status. It increases with tissue iron need and is more sensitive than other parameters to mild iron deficiency. The purpose of this study was to test its value in infants, a population especially susceptible to iron deficiency.

Methods and setting: We measured hemoglobin, serum ferritin (RIAgnost. Behring) and the serum transferrin receptor (CLINIGEN EIA. Amgen Diagnostics) in 71 healthy infants at 12 months of age from 5 centers of the Euro-Growth Study (Vienna, Salzburg, Budapest, Bilbao, Porto, Dublin). Results: Intra- and interassay variances of the transferrin receptor (TIR) measurements were $3.5 \%$ and $7.75 \%$, respectively. Infants with hemoglobin (Hb) levels $<11 \mathrm{~g} / \mathrm{dl}$, indicating anemia, had significantly higher TfR values than infants with $\mathrm{Hb}$ values $>11 \mathrm{~g} / \mathrm{dl}(3,46 \pm 0.99$ vs $2.66 \pm 1.04 \mathrm{ug} / \mathrm{ml} ; p<0.05$. Wilcoxon rank test). In infants with $\mathrm{Hb}>11 \mathrm{~g} / \mathrm{dl}$ and s-ferritin $<12$, between $12 \cdot 20$, and $>20$ $\mathrm{ng} / \mathrm{ml}$, TiR values were $3.04 \pm 1.13^{\circ}, 2.54 \pm 0.93$ and $2.18 \pm 0.64^{\circ} \mathrm{ug} / \mathrm{ml}$ respectively (" $p<0.05$, Duncans Multiple Range test). Regression analysis did respectively ( $(p<0.05$, Duncans Multiple Range test). Regression analys Conclusions: Serum transferrin receptor is significantly increased in infants with iron deficiency anemia. In infants with no anemia $(\mathrm{Hb}>11 \mathrm{~g} / \mathrm{dl})$ but low iron with iron deficiency anemia. In infants with no anemia $(\mathrm{Hb}>11 \mathrm{~g} / \mathrm{dl}$ ) but low iron
stores (s-territin $<20$ ) elevated transferrin receptor values already indicate iron stores (s-ferritin < 20) elevated transferrin receptor values already indicate iron
deficient erythropoeisis. Although our data are limited the combination of serum ferritin and serum transterrin receptor appears promising as a screening tool for mild iron deficiency in infants.
141

PROTEIN METABOLISM IN VENTILATED PRETERM INFANTS ON THF FIRST DAY OF LIFE.

J.B. Van Goudoever, J.L.D. Wattimena, P.J.J. Sauer. Department of Pediatrics Sophia Childrens Hospital, Erasmus University Rotterdam, The Netherlands.

Protein kinetics were measured to examine the effect of immediate commencement of amino acid (AA) administration following birth. Eight infants (birth wt $1.5 \pm 0.3 \mathrm{~kg}$ ) received exclusively $6.6 \pm 1.4 \mathrm{~g}$ glucose $/ \mathrm{kg} / \mathrm{s}(26 \mathrm{kcal} / \mathrm{kg} / \mathrm{d})$ and seven infants (bw $1.4 \pm 0.4 \mathrm{~kg}$ ) received $5.9 \pm 2.0 \mathrm{~g}$ glucose $/ \mathrm{kg} / \mathrm{d}$ and $1.2 \pm 0.1$ $\mathrm{g} \mathrm{AA} / \mathrm{kg} / \mathrm{d}(28 \mathrm{kcal} / \mathrm{kg} / \mathrm{d})$. All infants were ventilated and studied at the first day of life. A primed continuous infusion of $\mathrm{NaH}^{13} \mathrm{CO}_{3}$ was followed by a primed continuous infusion of $\left[1^{13} \mathrm{C}\right]$ leucine. Isotopic enrichment of expired $\mathrm{CO}_{2}$ was measured by IRMS and dilution of ${ }^{13} \mathrm{C}-\mathrm{KIC}$ was measured by GCMS. Nitrogen excretion was measured in urine. The results (mean $\pm S D$, $\dagger$ signediff. at $p \leq 0.01$ ): $\mathrm{N}$-balance Turnover Oxidation Synthesis Breakdown Balance $\mathrm{mg} / \mathrm{kg} / \mathrm{d}$ $\mu \mathrm{mol}$ leucine $/ \mathrm{kg} / \mathrm{hr}$

glucose $\quad-110 \pm 47201 \pm 20 \quad 41 \pm 13 \quad 160 \pm 20 \quad 186 \pm 20 \quad-27 \pm 13$ glu $+\mathrm{AA}+45 \pm 98+219 \pm 33 \quad 48 \pm 16 \quad 171 \pm 35 \quad 171 \pm 35+4 \pm 17 \dagger$ Conclusions: 1. Amino acid administration does not significantly alter leucine oxidation on the first day of life. 2. Even at a very low energy intake, amino acid administration of $1.2 \mathrm{~g} / \mathrm{kg} / \mathrm{d}$ prevents both negative leucine and nitrogen balances. Based upon protein balances, it seems that the administration of amino acids on the first day of life is benificial for preterm infants

\section{2}

MIXED MCT/LCT LIPID EMULSION USE IN SICK VLBW INFANTS David C Wilson, Kenry L Halliday, Mark Reid, Garth McClure, John A Dodge. Department of Child Health, The Queen's University of Belfast and Royal Maternity Hospital, Belfast.

Undernutrition is common in sick VLBW infants requiring parenteral nutrition (PN). Lipid-free PN leads to poor energy intake but lipid has been associated with increased energy intake but lipid has been associated with
incidences of infection and BPD. Medium chain inciglycerides (MCT) are metabolised faster than long chain triglycerides (MCT) are metabolised faster than long chain
(LCT). We therefore designed a new PN regimen, with use of a 50 . MCT emulsion from day 2 and in greater amounts. and compared this to a conventional PN regimen with 100 s LCT emulsion. Sick VLBW infants were randomised to this new PN regimen (MCT) or control (LCT) groups; Lipof und in MCT/LCT (B Braun) was used in the MCT group $(n=64)$ and Intralipid (Kabi Vitrum) in the LCT group $(n=61)$. The MCT group had a mean BW of $925 \mathrm{~g}$ compared to $933 \mathrm{~g}$ in the LCr group. Mean energy intakes whilst receiving $\mathrm{PN}$ were greater $(p<0.001)$ in the MCT group at days $7,14,21,28,35$ and 42 . The incidences of BPD were 29 in the MCT group and 298 in the LCT group (ns), with infection rates of 638 and 748 respectively (ns). There were no significant increases in incidences of hyperlipidaemia or hyperketonaemia in the MCT group. We conclude that liberal MCT emulsion usage lessens undernutrition without adverse clinical or metabolic sequelae in sick preterms. 